\title{
LEAF CONCENTRATIONS OF NITROGEN AND PHOSPHORUS IN Phaseolus vulgaris L. PLANTS UNDER HIGH $\mathrm{CO}_{2}$ CONCENTRATION AND DROUGHT STRESS
}

\author{
JOÃO B. L. DA SILVA ${ }^{1}$; PAULO A. FERREIRA ${ }^{2}$; FLÁVIO JUSTINO ${ }^{3}$; \\ LUANNA C. PIRES ${ }^{4}$; AMANDA S. TOLEDO
}

\begin{abstract}
This study aims to evaluate the leaf concentration of nitrogen and phosphorus correlated to the production of photoassimilates in beans plants (Phaseolus vulgaris L.) under high $\left[\mathrm{CO}_{2}\right]$ and drought stress. The experiment was conducted in Viçosa (Brazil), during the period from April to July 2009, by using open-top chambers equipped with $\mathrm{CO}_{2}$ injection system. The drought stress was applied, through the irrigation suspension, during the period from flowering to maturation. The experimental design was randomized blocks in split-plot scheme with four replication, where the plots with plants grown in $\left[\mathrm{CO}_{2}\right]$ of $700 \mathrm{mg} \mathrm{L}^{-1}$ and $\left[\mathrm{CO}_{2}\right]$ environment of $380 \mathrm{mg} \mathrm{L}^{-1}$ and the subplots with plants with and without drought stress. The results were submitted to ANOVA and Tukey test $(\mathrm{p}<0.05)$. In the plants under high $\left[\mathrm{CO}_{2}\right]$ with and without drought stress, the photosynthetic rate increased by $59 \%$, while the dry matter presented an increment of $20 \%$ in the plants under high $\left[\mathrm{CO}_{2}\right]$ without drought stress. Reductions in $[\mathrm{N}]$ and $[\mathrm{P}]$ occurred in plants grown under high $\left[\mathrm{CO}_{2}\right]$, resulting in greater efficiency in nitrogen use for photosynthesis. The high $\left[\mathrm{CO}_{2}\right]$ increase only the total dry matter and not the total mass of grains. The drought stress reduces the dry matter and mass of grain, even at high $\left[\mathrm{CO}_{2}\right]$.
\end{abstract}

KEYWORDS: beans, mineral nutrition, photosynthesis, climatic changes.

\section{NITROGÊNIO E FÓSFORO FOLIAR NO CRESCIMENTO DE PLANTAS DE FEIJÃO CULTIVADAS SOB ALTA [CO $\left.\mathrm{CO}_{2}\right]$ E DEFICIÊNCIA HÍDRICA}

RESUMO: Neste trabalho, as concentrações de nitrogênio e fósforo foliares foram analisadas e relacionadas com a produção de fotoassimilados do feijoeiro (Phaseolus vulgaris L.) cultivado sob alta concentração de $\mathrm{CO}_{2}$ e deficiência hídrica. O experimento foi realizado em Viçosa-MG, entre abril e julho de 2009, utilizando-se de câmaras de topo aberto equipadas com sistema de injeção de $\mathrm{CO}_{2}$. A deficiência hídrica foi aplicada pela supressão da irrigação, durante o período de floração à maturação. $\mathrm{O}$ delineamento experimental foi em blocos casualizados, tendo nas parcelas plantas cultivadas em $\left[\mathrm{CO}_{2}\right]$ a $700 \mathrm{ppm}$ e $\left[\mathrm{CO}_{2}\right]$ ambiente $(380 \mathrm{ppm})$, e nas subparcelas, plantas sem e com deficiência hídrica. Os resultados foram submetidos à Anova e ao teste de Tukey $(\mathrm{p}<0,05)$. Nas plantas sob alta $\left[\mathrm{CO}_{2}\right]$ e sem e com estresse hídrico, a taxa fotossintética aumentou $59 \%$, enquanto o crescimento analisado pela massa de matéria seca apresentou incremento de $20 \%$ nas plantas sob alta $\left[\mathrm{CO}_{2}\right]$ e sem estresse hídrico. Reduções nas $[\mathrm{N}]$ e $[\mathrm{P}]$ ocorreram nas plantas sob alta $\left[\mathrm{CO}_{2}\right]$, resultando em maior eficiência no uso do nitrogênio pela fotossíntese. A alta $\left[\mathrm{CO}_{2}\right]$ aumenta somente o total de massa seca da planta e não a massa de grãos. O estresse hídrico reduz a massa seca da planta e dos grãos, mesmo em alta $\left[\mathrm{CO}_{2}\right]$.

PALAVRAS-CHAVE: Phaseolus vulgaris L., nutrição mineral, fotossíntese, mudanças climáticas.

\footnotetext{
${ }^{1}$ Eng $^{\text {o }}$ Agrícola e Ambiental, Prof. Dr, Instituto de Humanidades, Artes e Ciências, UFSB/Teixeira de Freitas-BA, Fone: (73) $9192-$ 6885, silvajbl@yahoo.com.br;

${ }^{2}$ Eng $^{\circ}$ Agrônomo, Prof. Doutor, Departamento de Engenharia Agrícola, UFV/Viçosa - MG, pafonso@ufv.br;

${ }^{3}$ Meteorologista, Prof. Doutor, Departamento de Engenharia Agrícola, UFV/Viçosa - MG, fjustino@ufv.br;

${ }^{4}$ Zootecnista, Prof ${ }^{\text {a }}$. Doutora, Instituto de Humanidades, Artes e Ciências, UFSB/Teixeira de Freitas - BA,lualu66@yahoo.com.br;

${ }^{5}$ Enga Agrônomo, Doutoranda, Departamento de Engenharia Agrícola, UFV/Viçosa - MG,asantanatoledo@yahoo.com.br

Recebido pelo Conselho Editorial em: 27-6-2013

Aprovado pelo Conselho Editorial em: 4-5-2014
}

Eng. Agríc., Jaboticabal, v.34, n.5, p. 935-944, set./out. 2014 


\section{INTRODUCTION}

Recently, there has been an increasing fear how the future climate conditions may affect the productivity of crops (LUO et al., 2005; JAGGARD et al., 2007; COSTA et al., 2009). Among these futures climate conditions are the increase of $\mathrm{CO}_{2}$ concentration and alteration on the water availability (LUO et al., 2005; JAGGARD et al., 2007).

Today, the current concentration of $\mathrm{CO}_{2}\left(\left[\mathrm{CO}_{2}\right]\right)$ in the atmosphere is not able to saturate the photosynthetic process, being a limiting factor as for the growth and productivity of many species (AINSWORTH \& ROGERS, 2007). But in conditions of high $\left[\mathrm{CO}_{2}\right]$, studies indicate the possibility of changes in carbon/nitrogen relation $(\mathrm{C}: \mathrm{N})$ in plants with $\mathrm{C} 3$ photosynthetic metabolism (LEAKEY et al., 2009). This occurs due to high photosynthetic rates and biomass accumulation, with an average increase of $22 \%$ (SARDANS et al., 2012), in particular under nitrogen restrict availability, affecting crop productivity (SMITH et al., 2001). Despite the increase in photosynthesis and in the carbon allocation in plants exposed to high $\left[\mathrm{CO}_{2}\right]$, productivity is also associated with the increment in nutrients supply. In conditions of nutrient limitation, mainly nitrogen, leguminous plants such as common beans can be benefited at elevated $\left[\mathrm{CO}_{2}\right]$ due to nitrogen fixation. This further reduces the negative impacts of drought stress due to the fixation increase (ROGERS et al., 2009).

One should noted that due to the long time exposure to high $\left[\mathrm{CO}_{2}\right]$ during the cycle, many plants have presented significant photosynthetic down-regulation. This reduction in photosynthetic rate is induced by decrease in leaf nitrogen $[\mathrm{N}]$ and phosphorus $[\mathrm{P}]$ concentrations and stomatal conductance in response to high $\left[\mathrm{CO}_{2}\right]$ (SANZ-SÁEZ et al., 2010; LEE et al., 2011). The drought stress reduce the stomatal conductance too, besides the leaf $[\mathrm{N}]$ and $[\mathrm{P}]$, due the lower mineral absorbing. Also, the reduction in leaf $[\mathrm{N}]$ in plants under high $\left[\mathrm{CO}_{2}\right]$ (MIYAGI et al., 2007; GARTEN JR. et al., 2008; NIU et al., 2012), may result from physiological adjustment to increase the efficiency of nitrogen by high photosynthetic rate. This results in an increase in carbon absorbed rate per unit of leaf nitrogen and a decrease in leaf specific surface area and $[\mathrm{N}]$ per unit of dry matter. However, this increase in use efficiency of nitrogen by photosynthesis is also correlated with leaf phosphorus concentration (NIINEMETS et al., 1999). Reduction in leaf [N] in plants under high $\left[\mathrm{CO}_{2}\right]$ may also be related to weaker stomatal conductance (TAUB \& WANG, 2008), has been observed in plants under high [ $\mathrm{CO}_{2}$ ] (AINSWORTH \& ROGERS, 2007).

The common bean (Phaseolus vulgaris L.) presents a high degree of proteins, being responsible for much of the protein consumed worldwide, especially in Latin America and Africa. When grown in high $\left[\mathrm{CO}_{2}\right]$, and under potential supply of nitrogen fertilizer common beans presents increments between 40 and $80 \%$ in photosynthesis and 26 to $40 \%$ in dry matter. Leaf [N] in bean plants under high $\left[\mathrm{CO}_{2}\right]$ have shown a reduction between 31 to $35 \%$, if compared to plants under $\left[\mathrm{CO}_{2}\right]$ ambient atmosphere. Despite these positive responses to treatment with $\mathrm{CO}_{2}$, beans under high $\left[\mathrm{CO}_{2}\right]$ have presented photosynthetic down-regulation, especially in treatments with low nitrogen supply (JIFON \& WOLFE, 2002).

It is clear that several questions remain unresolved insofar the link between common beans productivity and the $[\mathrm{N}],[\mathrm{P}]$ and $\left[\mathrm{CO}_{2}\right]$ is concerned. Therefore, this study aims to evaluate the leaf concentration of nitrogen and phosphorus correlated to the production of photoassimilates in beans plants (Phaseolus vulgaris L.) under high $\left[\mathrm{CO}_{2}\right]$ and drought stress.

\section{MATERIAL AND METHODS}

The experiment was conducted at Lysimetric Station at the campus of the Federal University of Viçosa, Brazil $\left(20^{\circ} 45^{\prime} \mathrm{S}, 42^{\circ} 45^{\prime} \mathrm{W}\right)$, between April and July 2009. Lysimeters with $1.0 \mathrm{~m} \times 1.4$ $\mathrm{m}$ section and $0.8 \mathrm{~m}$ depth were divided by a metal plate septum, to perform the experimental design in subplots. The substrate to fill the lysimeters was a clayey dystrophic Red-Yellow Latosol, with very clayey texture, in which the acidity was corrected by liming (Table 1). Two fertilizations have been done during the experiment, a planting one with NPK 8-28-16, $650 \mathrm{~kg} \mathrm{ha}^{-1}$ and $300 \mathrm{~kg}$ 
$\mathrm{ha}^{-1}$ of magnesium sulfate, and the topdressing in the $16^{\text {th }}$ day after sowing (DAS) with $200 \mathrm{~kg} \mathrm{ha}^{-1}$ of urea and $250 \mathrm{~g} \mathrm{ha}^{-1}$ of sodium molybdate by leaf fertilization. The bean variety that has been used was Majestic-UFV (Phaseolus vulgaris L. cv. BRSMG Majestoso), carioca type of short cycle. The plant spacing was $0.05 \mathrm{~m}$ and between rows was $0.50 \mathrm{~m}$, totaling: 2 rows and 54 plants per lysimeter (plot); and one row and 27 per subplot.

TABLE 1. Analytical results of the soil substrate at $0-20 \mathrm{~cm}$ depth after correction of acidity by liming.

\begin{tabular}{|c|c|c|c|c|c|c|c|c|c|}
\hline $\begin{array}{c}\mathrm{pH} \\
\mathrm{H}_{2} \mathrm{O}\end{array}$ & $\begin{array}{c}\mathrm{P} \\
-\end{array}$ & K & $\mathrm{Zn}$ & $\begin{array}{c}\mathrm{Fe} \\
-\mathrm{mg}\end{array}$ & $\begin{array}{r}\mathrm{Mn} \\
\mathrm{m}^{-3}----\end{array}$ & $\mathrm{Cu}$ & B & $\mathrm{V} \quad \mathrm{m}$ & $\begin{array}{c}\text { Mo } \\
\text { dag kg }^{-1}\end{array}$ \\
\hline 6.2 & 27.3 & 142.0 & 10.0 & 71.2 & 4.9 & 0.7 & 0.1 & 41.0 & 16.0 \\
\hline $\mathrm{Ca}^{2+}$ & $\mathrm{Mg}^{2+}$ & $\mathrm{Al}^{3+}$ & $\begin{array}{l}\mathrm{H}+\mathrm{Al} \\
\mathrm{cmol}_{\mathrm{c}}\end{array}$ & $\begin{array}{c}\mathrm{SB} \\
\mathrm{m}^{-3}-\cdots\end{array}$ & $\mathrm{CEC}(\mathrm{E})$ & CEC(T) & $\begin{array}{l}\text { P-rem } \\
\text { mg L L }^{-1}\end{array}$ & Clay & Sand \\
\hline 1.7 & 0.6 & 0.0 & 3.8 & 2.7 & 2.7 & 6.5 & 13.3 & 70.0 & 21.0 \\
\hline
\end{tabular}

where, SSNa - Sodium Saturation index; BS - Sum Base; CEC (E) - Effective Cation Exchange Capacity; CEC (T) - Total Cation Exchange Capacity in pH 7,0; V - Base Saturation; m - Aluminum Saturation; e P-rem - Remaining Phosphorus.

All plants were grown in open top chambers composed by mobile rectangular modules $(1.8 \mathrm{x}$ $1.4 \times 0.9 \mathrm{~m})$, where the modules was added to follow the growth of plants $(1.8 \times 1.4 \times 0.5 \mathrm{~m})$, and provided with an internal air distribution system consisting of fans and perforated PVC pipes (Figure 1). Two $\left[\mathrm{CO}_{2}\right]$ were used in chambers, $380 \mathrm{mg} \mathrm{L}^{-1}$ (ambient) and $700 \mathrm{mg} \mathrm{L}^{-1}$. To have plants under $\left[\mathrm{CO}_{2}\right]$ of $700 \mathrm{mg} \mathrm{L}^{-1}$ a daily injection of $\mathrm{CO}_{2}$ between 6:00 to $18: 00$ from the $9^{\text {th }}$ and $90^{\text {th }}$ DAS have been applied. The temperature inside the chambers was, on average, $2^{\circ} \mathrm{C}$ above the external environment. Drip tapes were used in plant irrigation in order to maintain the soil closer to its field capacity $(\mathrm{FC}=33.62 \%)$. In plants subjected to drought stress, total irrigation suppression was done, between flowering ( $22^{\text {nd }}$ DAS) and maturation $\left(70^{\text {th }}\right.$ DAS), lasting 48 days. The water content in soil was monitored hourly by TDR (Time Domain Reflectometry), with probes installed at $0.20 \mathrm{~m}$ depth in soil and automatic.
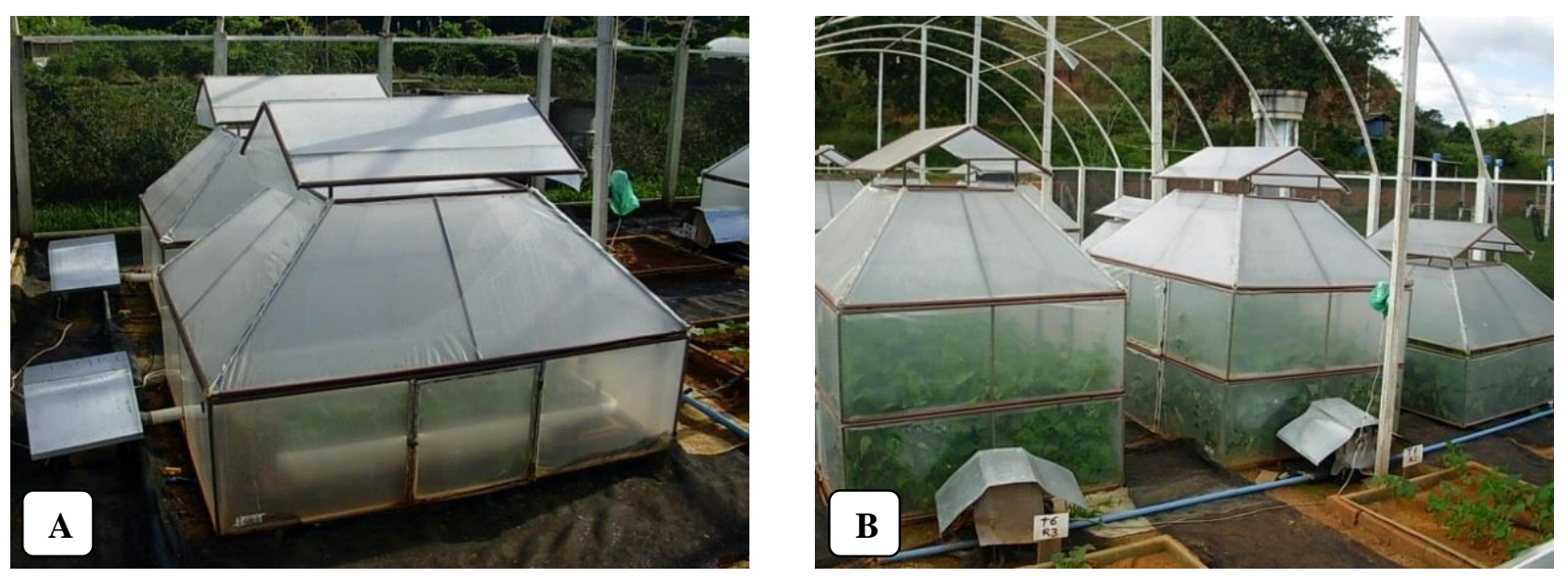

FIGURE 1. Open-top chambers composed by modules, added to follow the growth of plants: A chambers with a module, from $9^{\text {th }}$ to $40^{\text {th }}$ DAS, and B - chambers with two modules, from $41^{\text {st }}$ to $90^{\text {th }}$ DAS.

\section{Data collected}

The data collected were: leaf nitrogen concentration $([\mathrm{N}])$; leaf phosphorus concentration ([P]), photosynthetic rate $(A)$, chlorophyll total index $(C T)$ and total dry matter $(D M)$. The latest leaves developed were collected to determine the leaf $[\mathrm{N}]$ and $[\mathrm{P}]$, made a compose sample each sub-plot, to the leaf laboratorial analysis, as in Embrapa (2011). The photosynthetic rate was measured in the morning, between 8:00 and 11:00, with portable gas exchange meter (IRGA - Infra 
Red Gas Analyzer), with external radiation source system, 1,200 $\mu \mathrm{mol} \mathrm{J} \mathrm{m}^{-2} \mathrm{~s}^{-1}$ and the environmental conditions (temperature, $\left[\mathrm{CO}_{2}\right]$ and relative humidity) was the same inside the chambers. The chlorophyll total index was measured with a portable chlorophyll meter. Four measurements of photosynthetic rate, chlorophyll total index and total leaf concentration of nitrogen and phosphorus were performed: $1^{\text {st }}$ measurement, in the $20^{\text {th }}$ DAS (vegetative stage); $2^{\text {nd }}$ measurement, in the $41^{\text {th }}$ DAS (pre-flowering); $3^{\text {rd }}$ measurement, in the $67^{\text {th }}$ DAS (grain filling); and $4^{\text {th }}$ measurement, in the $82^{\text {nd }}$ DAP (maturation). The efficiency use of nitrogen for photosynthesis $(A N)$ was also determined, corresponding to the product of the photosynthetic rate $(A)$ by nitrogen concentration ([N]), as in LEE et al. (2011). At the end of the crop cycle, in the $100^{\text {th }}$ DAS, is was determinate the total mass of grains $(M G)$ and total dry matter $(D T)$, determined by the shoot of the plant dried in a ventilated oven at $70^{\circ} \mathrm{C}$ for three days.

\section{Experimental design and statistical analysis}

The experimental design was randomized blocks in split-plot scheme with four replications (blocks). The plots were the primary treatment $(\mathrm{F})$, or levels of $\left[\mathrm{CO}_{2}\right]$ : $\mathrm{F} 1$ - plants grown under $\left[\mathrm{CO}_{2}\right]$ to $700 \mathrm{mg} \mathrm{L}^{-1}$; and $\mathrm{F} 2$ - plants grown under $\left[\mathrm{CO}_{2}\right]$ ambient $\left(380 \mathrm{mg} \mathrm{L}^{-1}\right)$. The subplots were the secondary treatment (S), or water availability for crop: S1 - plants grown without drought stress; and S2 - plants grown under drought stress (Figure 2). The interactions resulted in four treatments: F1S1; F1S2; F2S1 and F2S2.

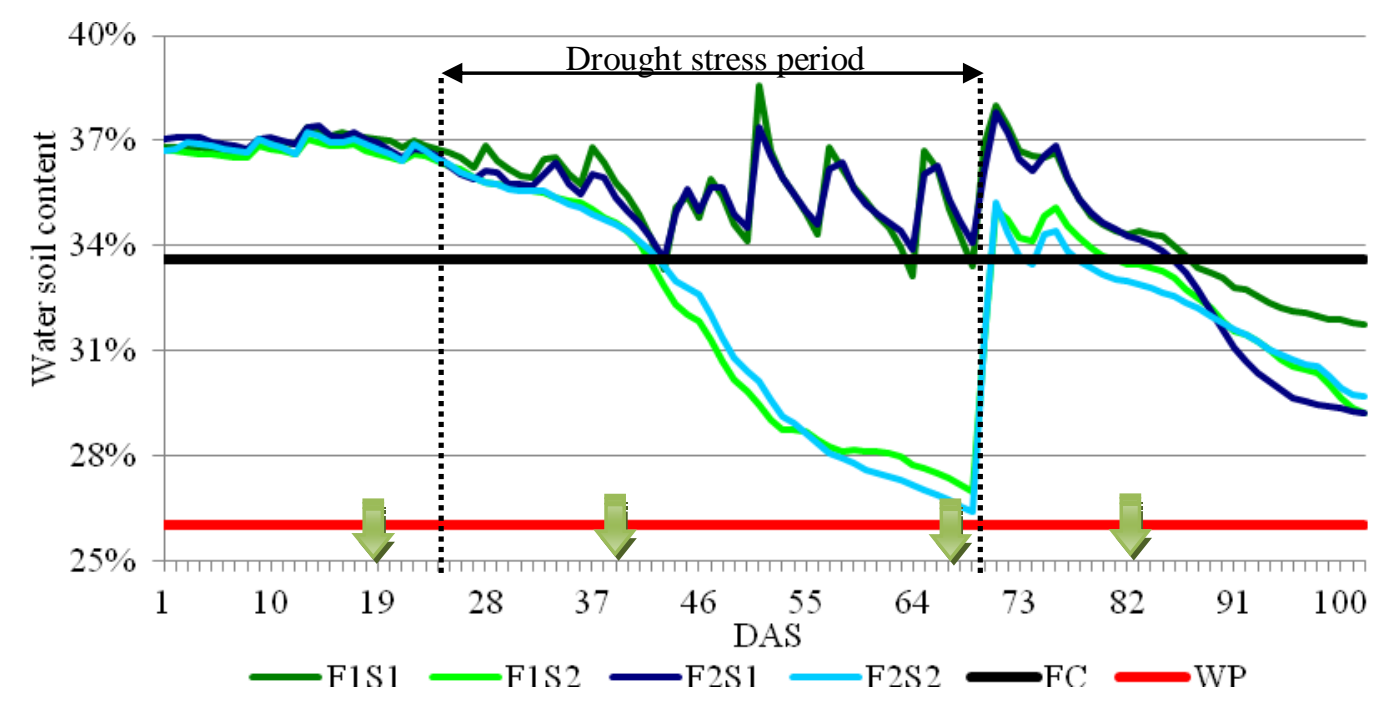

FIGURE 2. Water content in soil (\%) during the experiment for each treatment, field capacity (FC), witting point (WP), drought stress induction period and the four measurements (green arrows) of photosynthetic rate, total chlorophyll index and levels of leaf nitrogen and phosphorus.

First the variables were analyzed using simple descriptive statistics (mean, standard deviation and coefficient of variation), for further analysis of variance (ANOVA). As for the comparison of different levels of the plots, subplots and treatments, the Tukey test $(\mathrm{p}<0.05)$ has been applied. Moreover, a correlation test among all variables analyzed $(\mathrm{p}<0.05)$. All analyzes were performed using the statistical package SAS 9.3 (SAS, 2011).

\section{RESULTS AND DISCUSSION}

Measurements of photosynthetic rates $(A)$ demonstrated increments between 40 to $80 \%$ in plants under high $700 \mathrm{mg} \mathrm{L}^{-1}\left[\mathrm{CO}_{2}\right]$ (Table 2). These photosynthesis values were generally higher than those found by JIFON \& WOLFE (2002), BUNCE (2008) and LEE et al. (2011). These studies reported that photosynthetic rates increased between 13 to $60 \%$ for bean and other $\mathrm{C} 3$ plants under 
high $\left[\mathrm{CO}_{2}\right]$. The largest increase in photosynthetic rate, as compared to previous results, was a result of higher $\left[\mathrm{CO}_{2}\right]$ in the atmosphere in which the plants were grown, resulting in a higher gradient of $\left[\mathrm{CO}_{2}\right]$ between the environment and the leaf, increasing the availability of $\mathrm{CO}_{2}$ in Rubisco carboxylation site, which, probably, reduced photorespiration.

TABLE 2. Summary of descriptive analysis and variance for the four measurements of photosynthetic rate $(A 1, A 2, A 3$ and $A 4)$ and four measurements of leaf concentration of nitrogen $([\mathrm{N}] 1,[\mathrm{~N}] 2,[\mathrm{~N}] 3$ and $[\mathrm{N}] 4)$, together with the Tukey test

\begin{tabular}{|c|c|c|c|c|c|c|c|c|c|}
\hline \multicolumn{10}{|c|}{ Analysis of Variance (Anova) } \\
\hline \multirow{2}{*}{\multicolumn{2}{|c|}{$\begin{array}{l}\text { Source of } \\
\text { Variation }\end{array}$}} & $A 1$ & $A 2$ & $A 3$ & $A 4$ & {$[\mathrm{~N}] 1$} & {$[\mathrm{~N}] 2$} & {$[\mathrm{~N}] 3$} & {$[\mathrm{~N}] 4$} \\
\hline & & \multicolumn{4}{|c|}{----------- $\mu \mathrm{molCO}_{2} \mathrm{~m}^{-2} \mathrm{~s}^{-1}$} & \multicolumn{4}{|c|}{----------- dagN kg-1 ----------- } \\
\hline \multicolumn{2}{|l|}{$\mathrm{F}$} & $* *$ & $* *$ & $* *$ & $*$ & $*$ & * & $* *$ & $* *$ \\
\hline \multicolumn{2}{|l|}{$\mathrm{S}$} & NS & NS & $*$ & NS & NS & NS & NS & NS \\
\hline \multicolumn{2}{|c|}{$\mathrm{F} \times \mathrm{S}$} & NS & NS & $*$ & NS & NS & NS & $*$ & NS \\
\hline \multicolumn{2}{|c|}{ Mean } & 31.58 & 33.75 & 27.24 & 23.52 & 4.72 & 3.43 & 2.62 & 2.19 \\
\hline \multicolumn{2}{|c|}{ SD } & 5.13 & 8.69 & 4.50 & 5.34 & 0.33 & 0.44 & 0.35 & 0.19 \\
\hline \multicolumn{2}{|c|}{$\mathrm{CV}(\%)$} & 16.26 & 25.74 & 16.52 & 22.71 & 7.06 & 12.82 & 13.22 & 8.87 \\
\hline \multicolumn{10}{|c|}{ Tukey Test $(\mathrm{p}<0.05)^{1}$} \\
\hline \multirow{2}{*}{$\mathrm{F} 1$} & S1 & $41.02^{\mathrm{A}}$ & $44.32^{\mathrm{A}}$ & $37.69^{\mathrm{A}}$ & $29.72^{\mathrm{A}}$ & $4.53^{\mathrm{B}}$ & $2.92^{\mathrm{B}}$ & $1.88^{\mathrm{C}}$ & $1.71^{\mathrm{B}}$ \\
\hline & $\mathrm{S} 2$ & $34.48^{\mathrm{A}}$ & $39.15^{\mathrm{A}}$ & $37.80^{\mathrm{A}}$ & $27.73^{\mathrm{A}}$ & $3.98^{\mathrm{B}}$ & $2.67^{\mathrm{B}}$ & $2.12^{\mathrm{BC}}$ & $1.73^{\mathrm{B}}$ \\
\hline \multirow{2}{*}{$\mathrm{F} 2$} & $\mathrm{~S} 1$ & $24.27^{\mathrm{B}}$ & $24.93^{\mathrm{B}}$ & $22.46^{\mathrm{B}}$ & $18.96^{\mathrm{B}}$ & $5.31^{\mathrm{A}}$ & $4.23^{\mathrm{A}}$ & $3.68^{\mathrm{A}}$ & $2.65^{\mathrm{A}}$ \\
\hline & $\mathrm{S} 2$ & $26.55^{\text {В }}$ & $26.62^{\text {В }}$ & $11.02^{\mathrm{C}}$ & $17.67^{\mathrm{B}}$ & $5.09^{\mathrm{A}}$ & $3.92^{\mathrm{A}}$ & $2.79^{\mathrm{B}}$ & $2.67^{\mathrm{A}}$ \\
\hline
\end{tabular}

where: * significant to $\mathrm{p}<0.05 ; * *$ significant to $\mathrm{p}<0.01$; NS - not significant to $\mathrm{p}<0.05 ; \mathrm{F}$ - levels of $\left[\mathrm{CO}_{2}\right]\left(\mathrm{F} 1-\left[\mathrm{CO}_{2}\right]\right.$ at $700 \mathrm{mg}$ $\mathrm{L}^{-1} ; \mathrm{F} 2$ - $\left[\mathrm{CO}_{2}\right]$ at $380 \mathrm{mg} \mathrm{L}^{-1}$ ); S - water availability (S1 - well watering; S2 - drought stress); SD - standard deviation; and CV coefficient of variation. ${ }^{1}$ mean in same column follow to the same letter are equal for the Tukey Test.

The photosynthetic rate was highly affected by the interaction between the $\left[\mathrm{CO}_{2}\right]$ and water availability only after severe drought stress $\left(3^{\text {rd }}\right.$ measurement; Table 2$)$. The increased availability of $\mathrm{CO}_{2}$ was responsible for maintaining a high photosynthetic rate, even under drought stress, corroborating the observations of LEAKEY et al. (2009). They argued that plants exposed to high $\left[\mathrm{CO}_{2}\right]$ and under drought stress, like the interaction $\mathrm{F} 1 \mathrm{~S} 2$, do no experience decrease in photosynthetic rate in relation to plants under high $\left[\mathrm{CO}_{2}\right]$ and without drought stress, like the interaction F1S1. However, under current $\left[\mathrm{CO}_{2}\right]$, the effect of drought stress resulted in lower photosynthetic rate by approximately $50 \%$ (F2S2; Table 2).

The leaf concentration of nitrogen decreased throughout the crop cycle for all treatments (Table 2), which may be expected due to leaf senescence and displacement of the photoassimilates and nutrients to the grains (GARTEN JR. et al. 2008). On the other hand, MIYAGI et al., (2007) have shown increased nitrogen fixation by leguminous plants exposed to high $\left[\mathrm{CO}_{2}\right]$. We found that common beans under high $\left[\mathrm{CO}_{2}\right](\mathrm{F} 1)$ have presented throughout the cycle, lower $[\mathrm{N}]$ than plants exposed to ambient $\left[\mathrm{CO}_{2}\right]$ (F2; Table 2). Specifically, reductions have been noted in the first measurement ([N]1) between 15 to $25 \%$, second $([\mathrm{N}] 2)$ between 31 and $37 \%$, third $([\mathrm{N}] 3)$ between 42 and $49 \%$ and fourth ([N]4) 35\%. These reductions are higher than those found by DAVEY et al. (1999), 19\%, and LEE et al. (2011), 13\%. Thus, the reductions of leaf [N] in plants under high $\left[\mathrm{CO}_{2}\right]$ were due to increased demand, production of photoassimilates and dry matter (Table 3), resulted of the high photosynthetic rate that plants. But this high production of photoassimilates not increases total mass of grains $(M G)$, who suggest the high production of photoassimilates were drain to increase the dry matter, to produce leaves and shoots. In the third measurement ([N]3), exists an increase in the severity of drought stress in plants under ambient $\left[\mathrm{CO}_{2}\right]$ which leads to 
lower $[\mathrm{N}]$ as compared to plants without drought stress. This was due to the reduction in soil nitrogen absorption and inhibition of fixation of these plants (MIYAGI et al. 2007).

Plants under high $\left[\mathrm{CO}_{2}\right]$ and exposed to severe drought stress (F1S2) have not shown significant differences regarding plants of treatment F1S1, its might occur because, according to ROGERS et al. (2009), the high $\left[\mathrm{CO}_{2}\right]$ contributes to the maintenance of nitrogen fixation. The lower $[\mathrm{N}]$ throughout the growing cycle, in plants exposed to high $\left[\mathrm{CO}_{2}\right](\mathrm{F} 1)$, might indicate that do not occur higher nodulation or nitrogen fixation by plants, but maintenance of fixation during water stress (Table 2).

TABLE 3. Summary and descriptive analysis of variance for the four measurements of variables chlorophyll total index (CT1, CT2, CT3 and CT4), total mass of grains $(M G)$ and total dry matter $(D M)$, together with the Tukey test

\begin{tabular}{|c|c|c|c|c|c|c|}
\hline \multicolumn{7}{|c|}{ Analysis of Variance (Anova) } \\
\hline \multirow{2}{*}{$\begin{array}{l}\text { Source of } \\
\text { Variation }\end{array}$} & $C T 1$ & $C T 2$ & $C T 3$ & $C T 4$ & MG & $D M$ \\
\hline & ------ & chlorop & al inde & ------- & $\mathrm{g}$ & $g$ \\
\hline $\bar{F}$ & NS & NS & NS & NS & NS & NS \\
\hline S & NS & NS & NS & $*$ & $* * * *$ & $* * *$ \\
\hline $\mathrm{F} \times \mathrm{S}$ & NS & NS & NS & NS & NS & $*$ \\
\hline Mean & 50.00 & 54.06 & 50.42 & 42.07 & 395.23 & 796.47 \\
\hline SD & 3.23 & 3.47 & 4.01 & 4.80 & 58.91 & 59.25 \\
\hline \multirow[t]{2}{*}{$\mathrm{CV}(\%)$} & 6.45 & 6.41 & 7.96 & 11.40 & 19.30 & 7.44 \\
\hline & \multicolumn{6}{|c|}{ Tukey Test $(\mathrm{p}<0.05)^{1}$} \\
\hline \multirow{2}{*}{ F1 } & 49.49 & 54.16 & 48.20 & 37.24 & 478.23 & $1030.87^{\mathrm{A}}$ \\
\hline & 52.23 & 51.04 & 51.05 & 45.98 & 154.96 & $692.99^{\mathrm{BC}}$ \\
\hline & 48.66 & 53.41 & 47.76 & 40.89 & 417.14 & $825.79^{\text {B }}$ \\
\hline & 49.63 & 57.66 & 54.67 & 44.18 & 170.59 & $636.24^{\mathrm{C}}$ \\
\hline
\end{tabular}

where: * significant to $\mathrm{p}<0.05 ; * * *$ significant to $\mathrm{p}<0.001$; NS - not significant to $\mathrm{p}<0.05 ; \mathrm{F}$ - levels of $\left[\mathrm{CO}_{2}\right]\left(\mathrm{F} 1-\left[\mathrm{CO}_{2}\right]\right.$ at 700 $\mathrm{mg} \mathrm{L}^{-1} ; \mathrm{F} 2$ - $\left[\mathrm{CO}_{2}\right]$ at $\left.380 \mathrm{mg} \mathrm{L}^{-1}\right)$; S - water availability (S1 - well watering; S2 - drought stress); SD - standard deviation; and CV coefficient of variation. ${ }^{1}$ mean in same column follow to the same letter are equal for the Tukey Test.

Due to the high photosynthetic rates of plants under high $\left[\mathrm{CO}_{2}\right](\mathrm{F} 1 \mathrm{~S} 1)$, the dry matter $(D M)$ at the end of the crop cycle has shown a significant increase of $25 \%$ (Table 3), close to the value obtained by JIFON \& WOLFE (2002), NASSAR et al. (2008) and LEAKEY et al. (2009), but lower than that obtained by MIYAGI et al. (2007), 106\%. Common beans under high $\left[\mathrm{CO}_{2}\right]$ and drought stress (F1S2) experienced a distinct response, with a decrease of $16 \%$ in dry matter, while under atmosphere $\left[\mathrm{CO}_{2}\right]$ and drought stress (F2S2) experienced a decrease close to $23 \%$, lower that found by SILVEIRA \& STONE (2008). This indicates that high $\left[\mathrm{CO}_{2}\right]$ support only the photosynthetic rate, until the effects of severe drought stress are felt by plants resulting in leaves and pod fall and consequently reduced final dry matter $(D M)$ and mass of grains $(M G)$ (Table 3 ). The reduction of $63.64 \%$ in the total mass of grains $(M G)$ of plants subjected to drought stress was greater than that found by SAUCEDO et al. (2006) and SILVEIRA \& STONE (2008), approximately 30 and $42 \%$, respectively, possibly due to the magnitude and period of drought stress in this experiment, because according to DAVIES (2006), when the drought stress occurs in important stages of the plant, such as flowering and pod formation, the productivity losses are considerable. It should be noted that these results are very likely associated with the fact that measurements of photosynthetic rate are performed on fully expanded leaves, under ideal conditions of light, not reflecting the conditions of all the leaves of the plant. 
TABLE 4. Summary and descriptive analysis of variance for the four measurements of variables leaf concentration of $\mathrm{P}([\mathrm{P}] 1,[\mathrm{P}] 2,[\mathrm{P}] 3$ and $[\mathrm{P}] 4)$ and efficiency of nitrogen use for photosynthesis (AN1, AN2, AN3 and $A N 4)$, together with the Tukey test.

\begin{tabular}{|c|c|c|c|c|c|c|c|c|c|}
\hline \multicolumn{10}{|c|}{ Analysis of Variance (Anova) } \\
\hline \multirow{2}{*}{\multicolumn{2}{|c|}{$\begin{array}{l}\text { Source of } \\
\text { Variation }\end{array}$}} & $A N 1$ & AN2 & AN3 & AN4 & {$[\mathrm{P}] 1$} & {$[\mathrm{P}] 2$} & {$[\mathrm{P}] 3$} & {$[\mathrm{P}] 4$} \\
\hline & & \multicolumn{8}{|c|}{------- $\mu \mathrm{molCO}_{2} \mathrm{~m}^{-2} \mathrm{~s}^{-1} \mathrm{dagN}^{-1} \mathrm{~kg}-------$} \\
\hline \multicolumn{2}{|l|}{$\bar{F}$} & $*$ & $*$ & $* *$ & $* *$ & NS & $*$ & $*$ & $* *$ \\
\hline \multicolumn{2}{|l|}{ S } & NS & NS & NS & NS & NS & NS & NS & NS \\
\hline \multicolumn{2}{|c|}{$\mathrm{F} \times \mathrm{S}$} & NS & NS & NS & NS & NS & NS & $* *$ & NS \\
\hline \multicolumn{2}{|c|}{$\overline{\text { Mean }}$} & 6.94 & 10.80 & 12.12 & 11.85 & 0.33 & 0.21 & 0.16 & 0.16 \\
\hline \multicolumn{2}{|c|}{$\mathrm{SD}$} & 1.28 & 3.12 & 3.18 & 3.82 & $2.0010^{-2}$ & 0.04 & 0.03 & 0.02 \\
\hline \multicolumn{2}{|c|}{$\mathrm{CV}(\%)$} & 18.50 & 28.93 & 26.25 & 32.22 & 6.07 & 18.57 & 15.68 & 15.01 \\
\hline \multicolumn{10}{|c|}{ Tukey Test $(\mathrm{p}<0.05)^{1}$} \\
\hline & S1 & $9.11^{\mathrm{A}}$ & $15.18^{\mathrm{A}}$ & $19.99^{\mathrm{A}}$ & $17.64^{\mathrm{A}}$ & 0.33 & $0.18^{\mathrm{B}}$ & $0.10^{\mathrm{B}}$ & $0.14^{\mathrm{B}}$ \\
\hline & S2 & $8.79^{\mathrm{A}}$ & $15.19^{\mathrm{A}}$ & $18.36^{\mathrm{A}}$ & $16.07^{\mathrm{A}}$ & 0.29 & $0.14^{\mathrm{B}}$ & $0.16^{\mathrm{B}}$ & $0.16^{\mathrm{B}}$ \\
\hline \multirow{2}{*}{$\mathrm{F} 2$} & S1 & $4.62^{\mathrm{B}}$ & $5.92^{\mathrm{B}}$ & $6.16^{\mathrm{B}}$ & $7.10^{\mathrm{B}}$ & 0.36 & $0.27^{\mathrm{A}}$ & $0.22^{\mathrm{A}}$ & $0.17^{\mathrm{A}}$ \\
\hline & $\mathrm{S} 2$ & $5.24^{\mathrm{B}}$ & $6.93^{\mathrm{B}}$ & $3.96^{\mathrm{B}}$ & $6.58^{\mathrm{B}}$ & 0.34 & $0.26^{\mathrm{A}}$ & $0.16^{\mathrm{AB}}$ & $0.18^{\mathrm{A}}$ \\
\hline
\end{tabular}

where: * significant to $\mathrm{p}<0.05 ; * *$ significant to $\mathrm{p}<0.01$; NS - not significant to $\mathrm{p}<0.05 ; \mathrm{F}$ - levels of $\left[\mathrm{CO}_{2}\right]\left(\mathrm{F} 1-\left[\mathrm{CO}_{2}\right]\right.$ at $700 \mathrm{mg}$ $\mathrm{L}^{-1} ; \mathrm{F} 2$ - $\left[\mathrm{CO}_{2}\right]$ at $380 \mathrm{mg} \mathrm{L}^{-1}$ ); S - water availability (S1 - well watering; S2 - drought stress); SD - standard deviation; and CV coefficient of variation. ${ }^{1}$ mean in same column follow to the same letter are equal for the Tukey Test.

The leaf phosphorus concentration, [P], has shown a similar response to $[\mathrm{N}]$, with significant reductions in $[\mathrm{P}]$ over the cycle in plants exposed to high $\left[\mathrm{CO}_{2}\right](\mathrm{F} 1)$. In the second measurement ([P]2), the reduction was between 33 to $48 \%$, in the third ([P]3), from 27 to $55 \%$ and in the fourth ([P]4), between 6 to $18 \%$ (Table 4). The reductions in $[\mathrm{P}]$ in $\mathrm{C} 3$ leguminous plants under high $\left[\mathrm{CO}_{2}\right]$ have been also found by NIINEMETS et al. (1999), with reductions of $53 \%$ in [P] leaf, and JIN et al. (2012). This drop in [P] in plants under high $\left[\mathrm{CO}_{2}\right]$ is associated with increased demand of nutrients due to enhanced production of photoassimilates and dry matter (Table 2), once the plant metabolism was grow, like the Rubisco Enzyme activate, Calvin Cycle and Electron Transportation (AINSWORTH \& LONG, 2004).

Due to the high photosynthetic rates $(A)$ and low concentrations of nitrogen $([\mathrm{N}])$ in plants under high $\left[\mathrm{CO}_{2}\right]$ (Table 2), the efficiency of nitrogen use in photosynthesis $(A N)$ was higher in these plants throughout the cycle (Table 4), with increments of $82 \%$ in the first measurement (AN1), $136 \%$ in the second measurement (AN2), 279\% in the third measurement (AN3) and 146\% in the fourth measurement (AN4). These increases in $A N$ were greater than those found by LEE et al. (2011), 21\% for common beans. This increase in the efficiency of nitrogen use by photosynthesis was also reported by DAVEY et al. (1999).

Despite these differences in the concentrations of nitrogen and phosphorus in plants subjected to the applied treatments discussed above, no significant differences in the rate of chlorophyll total index $(C T)$ were found insofar the first three measurements have been concerned (Table 3). The only significant difference $(\mathrm{p}<0.05)$ has occurred in the last measurement, but only under drought stress (S). Plants experiencing drought stress had higher levels of chlorophyll total index $(C T)$, due to higher stock of nitrogen in the soil which was not consumed during drought stress. NIINEMETS et al. (1999) have no also found reduction in the concentration of chlorophyll in C3 plants under high $\left[\mathrm{CO}_{2}\right]$.

The Pearson correlations ( $r$ ) between the characteristics evaluated were largely nonsignificant $(\mathrm{p}>0.05)$ and positive (Table 5). The efficiency of nitrogen use for photosynthesis $(A N)$ showed a strong negative correlation with leaf phosphorus concentration, corroborating the 
observations of NIINEMETS et al. (1999). The $A N$ has also shown strong correlation with photosynthetic rate $(A)$ and high negative correlation with nitrogen concentration $([\mathrm{N}])$. This may be anticipated because $A N$ is the product of the $A$ times the $[\mathrm{N}]$. The nitrogen concentration has shown a strong correlation with the concentration of phosphorus, because the both absorption is related to each other.

TABLE 5. Estimates of the Pearson correlation of coefficients ( $r$ ) between all variables and $t$ test for correlations

\begin{tabular}{|c|c|c|c|c|c|c|c|}
\hline & {$[\mathrm{N}]$} & {$[\mathrm{P}]$} & $A$ & $C T$ & $D M$ & $A N$ & $M G$ \\
\hline$[\mathrm{N}]$ & 1.0000 & & & & & & \\
\hline$[\mathrm{P}]$ & $0.9122 * * *$ & 1.0000 & & & & & \\
\hline$A$ & $-0.0744^{\mathrm{NS}}$ & $-0.0485^{\mathrm{NS}}$ & 1.0000 & & & & \\
\hline$C T$ & $0.3340 * * *$ & $0.2460 *$ & $0.1615^{\mathrm{NS}}$ & 1.0000 & & & \\
\hline$D M$ & -0.1097 NS & $-0.0817^{\mathrm{NS}}$ & $0.5133 *$ & $-0.4053^{\mathrm{NS}}$ & 1.0000 & & \\
\hline$A N$ & $-0.6902 * * *$ & $-0.5993 * * *$ & $0.7039 * * *$ & $-0.1646^{\mathrm{NS}}$ & $0.3895^{\mathrm{NS}}$ & 1.0000 & \\
\hline$M G$ & $0.1726^{\mathrm{NS}}$ & $0.0866^{\mathrm{NS}}$ & $0.2285^{\mathrm{NS}}$ & $-0.5452 *$ & $0.8690 * * *$ & $0.1084^{\mathrm{NS}}$ & 1.0000 \\
\hline
\end{tabular}

The results obtained in this study corroborate the observations made by SORATTO (2004), who claimed that it is possible to use the chlorophyll total index $(C T)$ as indicative of the nitrogen content in the leaf and, hence, the need for fertilization in the culture (Table 5). The chlorophyll total index was also significantly correlated with the concentration of leaf phosphorus. This result differs from that of NIINEMETS et al. (1999), because the chlorophyll total index (CT) show negative correlation with total mass of grains $(M G)$. Different of the final dry matter of common beans $(D M)$, have shown significant correlation with the photosynthetic rate $(A)$ and (strong significant) total mass of grains $(M G)$, which may indicate increased production of photoassimilates under high $\left[\mathrm{CO}_{2}\right]$. But this increased production of photoassimilates were only to increase leaves and shoots.

\section{CONCLUSIONS}

Leaf concentrations of nitrogen and phosphorus are lower in bean plants exposed to high concentrations of $\mathrm{CO}_{2}$, with similar reductions for both nutrients. These low concentrations result from an increased production of photoassimilates but only on dry matter, leaves and shoots. Plants under ambient $\mathrm{CO}_{2}$ concentration and without drought stress present higher leaf concentrations of nitrogen and phosphorus than plans under drought stress and/or high $\mathrm{CO}_{2}$ concentration. Due to the increase in photosynthetic rate and the reduction in leaf concentration of nitrogen, plants grown under high $\mathrm{CO}_{2}$ concentration have shown greater efficiency in nitrogen use for photosynthesis.

The final dry matter is bigger in bean plant exposed to high concentrations of $\mathrm{CO}_{2}$ without drought stress, but this increase production of photoassimilates are only to increase leaves and shoots, not grain. The final dry matter presents positive correlation with the photosynthetic rate and total mass of grains.

The drought stress reduces the dry matter and mass of grain, same with high $\left[\mathrm{CO}_{2}\right]$.

\section{ACKNOWLEDGEMENTS}

To FAPEMIG and CNPq for the project funding. 


\section{REFERENCES}

AINSWORTH, E.A.; LONG, S.P. What have we learned from 15 years of free air- $\mathrm{CO}_{2}$ enrichment (FACE)? A meta-analytic review of the responses of photosynthesis, canopy properties and plant production to rising $\mathrm{CO}_{2}$. New Phytologist, Cambridge, v.165, p.351-372, 2005.

AINSWORTH, E. A.; ROGERS, A. The response of photosynthesis and stomatal conductance to rising $\left[\mathrm{CO}_{2}\right]$ : mechanisms and environmental interactions. Plant, Cell and Environment, Oxford, v. 30, p. 258-270, 2007.

BUNCE, J. A. Contrasting responses of seed yield to elevated carbon dioxide under filed conditions within Phaseolus vulgaris. Agriculture, Ecosystems and Environment, Amsterdam, v. 128, p. 219224, 2008.

COSTA, L. C.; JUSTINO, F. B.; OLIVEIRA, L. J. C.; SEDIYAMA, G. C.; FERREIRA, W. P. M.; LEMOS, C. F. Potential forcing of $\mathrm{CO}_{2}$, technology and climate changes in maize (Zea Mays) and bean (Phaseolus vulgaris) yield in southeast Brazil. Environmental Research Letters, Bristol, v. 4, p. 1-10, 2009.

DAVEY, P. A.; PARSONS, A. J.; ATKINSON, L.; WADGE, K.; LONG, S. P. Does photosynthetic acclimation to elevated $\mathrm{CO}_{2}$ increase photosynthetic nitrogen-use efficiency? A study of three native UK grassland species in open-top chambers. Functional Ecology, Oxford, v. 13, p. 21-28, 1999.

DAVIES, W. J. Responses of plant growth and functioning to changes in water supply in a changing climate. In: MORISON, J.; MORECROFT, M. Plant growth and climate change. Oxford: Blackwell Publishing, 2006, 213p.

EMBRAPA. Manual de análises químicas de solos, plantas e fertilizantes. 2. ed. Brasilia-DF, 2011. 230p.

GARTEN JR, C. T.; CLASSEN, A. T.;NORBY, R. J.;BRICE, D. J.;WELTZIN, J. F.;SOUZA, L. Role of $\mathrm{N}_{2}$-fixation in constructed old-field communities under different regimes of $\left[\mathrm{CO}_{2}\right]$, temperature, and water availability. Ecosystems, New York, v. 11, p. 125-137, 2008.

JAGGARD, K. W.; QI, A.; SEMENOV, M. A. The impact of climate change on sugarbeet yield in the UK: 1976-2004. The Journal of Agricultural Science, New York, v. 145, p. 367-375, 2007.

JIFON, J. L.; WOLFE, D. W. Photosynthetic acclimation to elevated $\mathrm{CO}_{2}$ in Phaleseolus vulgaris L. is altered by growth response to nitrogen supply. Global Change Biology, Oxford, v. 8, p.10181027, 2002.

JIN, J.; TANG, C.; ARMSTRONG, R.; SALE, P. Phosphorus supply enhances the response of legumes to elevated $\mathrm{CO}_{2}$ (FACE) in a phosphorus-deficient vertisol. Plant and Soil, Dordrecht, v. 358, p. 91-104, 2012.

LEAKEY, A. D. B.; AINSWORTH, E. A.; BERNACCHI, C. J.; ROGERS, A.; LONG, S. P.; ORT, D. R. Elevated $\mathrm{CO}_{2}$ effects on plant carbon, nitrogen, and water relations: six important lessons from FACE. Journal of Experimental Botany, Oxford, v. 60, n. 10, p. 2859-2876, 2009.

LEE, T. D.; BARROTT, S. H.; REICH, P. B. Photosynthetic responses of 13 grassland species across 11 years of free-air $\mathrm{CO}_{2}$ enrichment is modest, consistent and independent of $\mathrm{N}$ supply. Global Change Biology, Oxford, v. 17, p. 2893-2904, 2011.

LUO, Q.; BELLOTI, W.; WILliAMS, M.; BRYAN, B. Potential impact of climate change on wheat yield in South Australia. Agricultural and Forest Meteorology, Amsterdam, v. 132, p. 273$285,2005$.

MIYAGI, K. M.; KINUGASA, T.; HIKOSAKA, K.; HIROSE, T. Elevated $\mathrm{CO}_{2}$ concentration, nitrogen use, and seed production in annual plants. Global Change Biology, Oxford, v. 13, p. 2161$2170,2007$. 
NASSER, R. R.; FULLER, M. P.; JELLINGS, A. J. Effect of elevated $\mathrm{CO}_{2}$ and nitrogen levels on lentil growth and nodulation. Agronomy for Sustainable Development, Paris, v. 28, p. 175-180, 2008.

NIINEMETS, Ü. et al. Interactive effects of nitrogen and phosphorus on the acclimation potential of foliage photosynthetic properties of cork oak, Quercussuber, to elevated atmospheric $\mathrm{CO}_{2}$ concentrations. Global Change Biology, Oxford, v. 5, p. 455-470, 1999.

NIU, Y.; CHAI, R.; DONG, H.; WANG, H.; TANG, C.; ZHANG, Y. Effect of elevated $\mathrm{CO}_{2}$ on phosphorus nutrition of phosphate-deficient Arabidopsis thaliana (L.) Heynh under different nitrogen forms. Journal of Experimental Botany, Oxford, v. 64, n. 1, p. 355-367, 2012.

ROGERS, A.; AINSWORTH, E.; LEAKEY, A. D. B. Will elevated carbon dioxide concentration amplify the benefits of nitrogen fixation in legumes? Plant Physiology, Minneapolis, v. 151, p. 1009-1016, 2009.

SANZ-SÁEZ, A.; ERICE, G.; ARANJUELO, I.; NOGUÉS, S.; IRIGOYEN, J. J.; SÁNCHEZDÍAZ, M. Photosynthetic down-regulation under elevated $\mathrm{CO}_{2}$ exposure can be prevented by nitrogen supply in nodulated alfalfa. Journal of Plant Physiology, Jena, v. 167, n. 18, p. 1558-1565, 2010.

SARDANS, J.; RIVAS-UBACH, A.; PEÑUELAS, J. The C:N:P stoichiometry of organisms and ecosystems in a changing world: A review and perspectives. Perspectives in Plant Ecology, Evolution and Systematics, Jena, v. 14, p. 33-47, 2012.

SAS. User's guide. Versão 9.3. Cary: SAS Institute, 2011.

SAUCEDO, M. C. C.; TELLEZ, L. C.; HERNANDEZ, V. A. G.; ALVARADO, A. D.; VARELA, A. S.; SANTOS, G. G. Physiological responses, yield and seed quality of dry bean submitted to drought stress. Interciencia, Amsterdam, v. 31, p. 461-466, 2006.

SILVEIRA, P. M.; STONE, L. F. Irrigação. In: VIEIRA, C.; PAULA JÚNIOR, T. J.; BORÉM, A. Feijão. 2. Ed. Viçosa: UFV, 2008. 600p.

SMITH, W. N.; DESJARDINS, R. L.; GRANT, B. Estimated changes in soil carbon associated with agricultural practices in Canada. Canadian Journal of Soil Science, Ottawa, v. 81, n. 2, p. 221$227,2001$.

SORATTO, R. P.; CARVAlHO, M. A. C.; ARF, O. O. Teor de clorofila e produtividade do feijoeiro em razão da adubação nitrogenada. Pesquisa Agropecuária Brasileira, Brasília, v. 39, n. 9, p. 895-901, 2004.

TAUB, D.R.; WANG, X. Why are Nitrogen Concentrations in Plant Tissues Lower under Elevated $\mathrm{CO}_{2}$ ? A Critical Examination of the Hypotheses. Journal of Integrative Plant Biology, Malden, $\mathrm{v}$. 50, n. 11, p. 1365-1374, 2008. 